\title{
Major Climatic Changes Experienced by Farm Households: Evidence from the Lowlands of Southern Ethiopia
}

\author{
A. Aboye ${ }^{1}$, J. Kinsella², T. Leza ${ }^{3}$
}

\begin{abstract}
Ethiopia is one of the world's most vulnerable countries experiencing drought and floods as a result of climate variability and change. This study examined the major climatic changes experienced by farm households in the lowlands of Southern Ethiopia. It utilized a mixed methods sequential explanatory design approach to triangulate quantitative data with qualitative data. Using a multistage sampling procedure, 400 farm household heads participated. Moreover, meteorological data were acquired from the National Meteorology Agency for the period from 2000 to 2019. Descriptive statistics, rainfall anomalies, and coefficient variation were used for data analysis. The findings show that over the last 20 years, the frequency and intensity of extreme weather had increased, and there was an overall change in the seasonality of rainfall. Drought assessment results showed that 2004, $2009,2012,2015$, and 2017 were all drought years in the study districts. The results revealed that reduced crop production, flooding, crop losses, drought, malaria, and animal disease were the major climate change impacts that farm households experienced in the lowlands of Southern Ethiopia. The study suggests that drought-resistant crops and water harvesting schemes should be promoted to minimize the effects of climate change.
\end{abstract}

\section{Keywords}

Climate variability, farmers' observations, vulnerable hot-spots, adaptive capacity

1. Almaz Balta Aboye, Assistant Professor of Rural Development, Wolaita Sodo University, PO Box 138, Wolaita Sodo Ethiopia, Ethiopia.almaza.boye@ucdconnect.ie, iD https://orcid.org/0000-0002-3038-6501

2. Jim Kinsella, Professor of Agricultural Extension and Rural Development, University College Dublin, Belfield Dublin 4 Ireland, jim.kinsella@ucd.ie, (ID https://orcid.org/0000-0002-6556-3555

3. Tekle Leza, Associate Professor of Rural Development, Wolaita Sodo University, PO Box 138, Woliata Sodo Ethiopia., Tekle.leza@yahoo.com, (iD https://orcid.org/0000-0002-4065-0281 


\section{Introduction and Problem Statement}

Climate change is a critical development challenge (Kolawole et al., 2016). It is considered one of the biggest challenges of the 21st century, globally impacting people's lives (Abidoy \& Odusola, 2015). Its' severity is high in Africa, whose main economic activities largely depend on climate-sensitive sectors (Kolawole et al., 2016). Climate change impacts all economic sectors, with agriculture being one of the most sensitive and intrinsically vulnerable (Paul et al., 2016). In Ethiopia, the impact of climate change on the socio-economic fabric of society is tremendous (Auci et al., 2018). The southern parts of Ethiopia are most vulnerable, with significant rainfall variability and change resulting in prolonged drought and flood occurrences (Belay et al., 2021).

Wolaita Zone in Southern Ethiopia has a high population density and is largely dependent on small-scale, labour-intensive agriculture. Itis one of the most climate-vulnerable hotspots in Africa underpinned with a very weak adaptive capacity (Bedeke et al., 2018). The amount, duration, and intensity of rainfall in the zone varies considerably, generally decreasing from highland to lowlands (Wolaita Zone Finance and Economic Development Department [WZFEDD], 2017). Studies (Bedeke et al., 2018; Bekele et al., 2020; Mihiretu et al., 2020; Tessema \& Simane, 2020) have been undertaken in different agroecological zones throughout Ethiopia to assess farm households' perceptions of climate variability. Understanding the historical and projected implications of climate change on agriculture and farm household livelihoods is critical for a country's development of climate-resilient systems (Georgis, 2015). This study examined the major climatic changes experienced by farm households in the lowlands of Wolaita, Southern Ethiopia, and aimed to inform stakeholders on actions that can be taken to address these vulnerabilities.

\section{Theoretical and Conceptual Framework}

The livelihoods of the majority of people in the study area are dependent on agriculture, which in turn is highly impacted by climate change. Therefore, the theoretical framework that is adapted for this study takes into consideration this reality and is based on the sustainable livelihood framework designed by Department for International Development London (DIFD,1999). The paper does not address all the elements of the framework and focuses on the vulnerability context in terms of the impact of climate change while accepting other important factors combine with climate change to create the vulnerability context of the time.

Climate-induced hazards such as droughts, floods, and rising temperatures pose a major threat to the livelihoods of the poor in Ethiopia (Bekele et al., 2020). The impact of climate change is expected to heighten the vulnerability of both humans and animals (Intergovernmental Panel on Climate Change [IPCC], 2018). The Ethiopia Climate Action Report (Irish Aid, 2017) noted that climate change and its associated variability in Ethiopia influence crop planting times, length of growing seasons, shifts in crop types or cultivars, pest and weed prevalence, as well as the frequency of crop failures. 
Climate change is the result of greenhouse gas emissions, much of which is caused by human activities and natural cycles (National Research Council [NRC],. NRC (2020) noted certain endothermic gases (such as carbon dioxide) are warming the earth and increasingly, humans are influencing the climate and temperature of the earth by burning fossil fuels, cutting down forests, and farming livestock. This adds a large amount of greenhouse gases to the ones naturally produced in the atmosphere, which intensifies the greenhouse effect and global warming (IPCC, 2018; Kaddo, 2016; Trenberth, 2018). However, the biggest contribution of greenhouse gas emissions (71\%) comes from agriculture and land-use and/or land-use change activities (Crippa, et al 2021).

Figure 1 presents the conceptual framework for this study and suggests the causes and effects of climate change on farm household livelihoods. The temperature change and rainfall variability as a consequence of climate change gives rise to droughts, floods, consequential changes in agricultural production, and the prevalence of human and animal diseases. These changes adversely affect the livelihoods of farm households including those who live in the lowlands of Ethiopia.

\section{Figure 1}

The Climatic and Farming Factors Affecting Farm Households' Livelihoods in Ethiopia (Study Conceptual Framework)

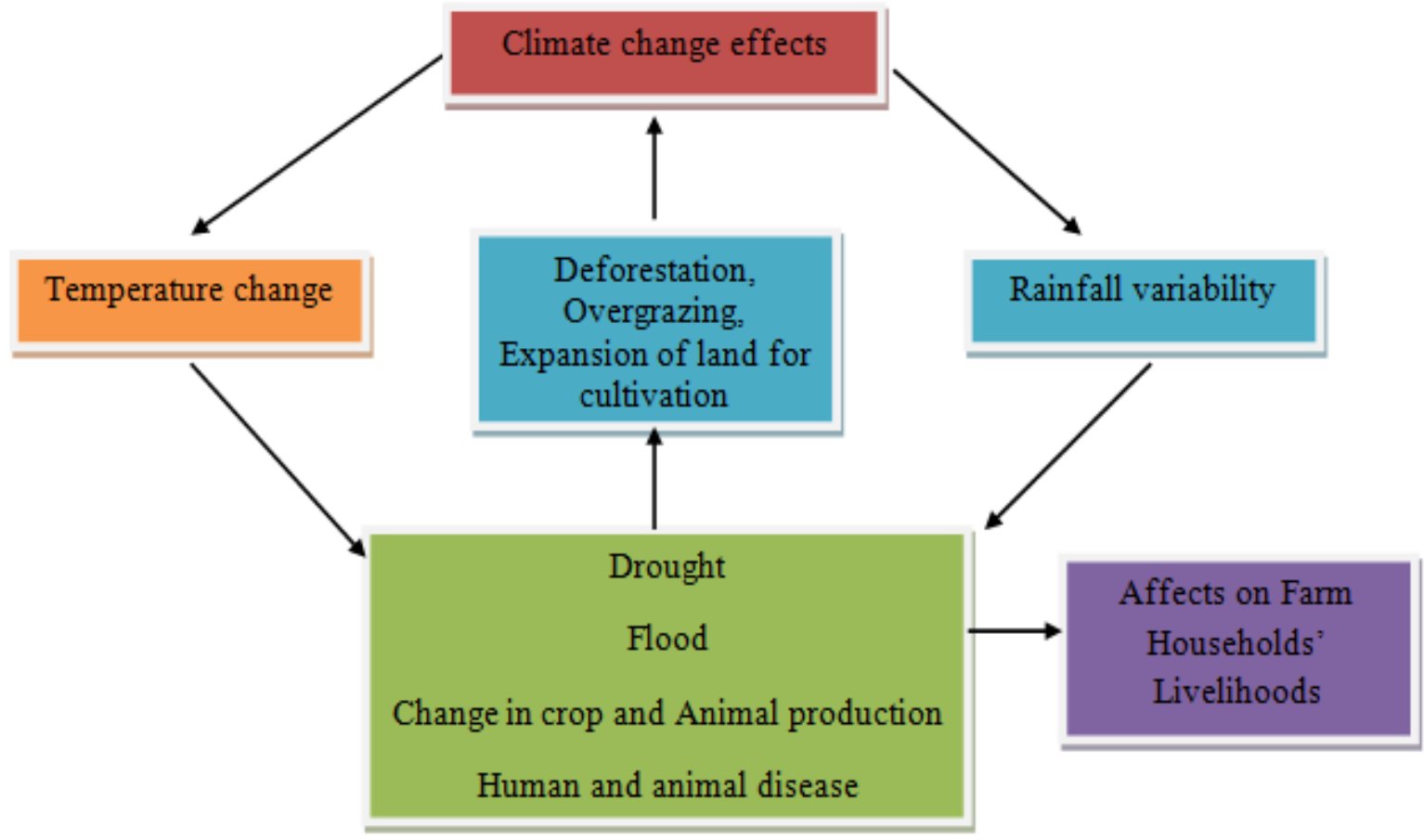




\section{Purpose}

The purpose of the study was to examine the major climatic changes that agricultural households in the lowlands of Southern Ethiopia have been experiencing. The objectives were:

- To determine how farmers perceived long-term climate changes.

- To examine climate change variability in the study area using twenty years of climate data (from 2000 through to 2019).

- To assess how farm households experienced climate change impacts in their livelihoods.

\section{Methods}

This study applied a mixed-methods sequential explanatory design to triangulate the data collected. Multi-stage sampling procedures were applied to choose the sample of respondents for the household survey. Wolaita Zone was purposively selected at the principal stage as it is one of the most climate-vulnerable zones in the Southern Region of the country. Out of the 16 districts in the Zone, four of them, namely Duguna Fango, Damot Woyede, Abala Abaya, and Kindo Koyisha, were purposively selected because of their relatively large areas of lowland. Two villages from each district were then randomly selected. The Cochran's (1977) formula $n_{\mathrm{o}}=Z^{2} p q / e^{2}$ was used to determine the sample size of the study population. Where $n_{\mathrm{o}}$ is the sample size, e is the desired level of precision with a $95 \%$ confidence level, $p$ is the estimated proportion of an attribute that is present in the population, and q is 1-p. Finally, 400 respondents were selected from the eight chosen villages by employing systematic random sampling based on the probability proportional to size.

A structured questionnaire was used to collect household data. For this, four data collectors were recruited and trained. The questionnaire was pre-tested and contained both open and closed questions. Based on testing results the questionnaire was revised and refined. The finalized survey was conducted between September 2020 and November 2020. Focus group discussions (FGD) were held in each of the selected villages. The FGD participants were purposefully selected by considering farming experiences (men and women). In each FGD group, eight men and women farmers from the local area participated. Semi-structured interviews were employed to collect qualitative data and researcher field notes and records were kept. The study obtained ethical clearance from University College Dublin, Ireland, and Wolaita Sodo University, Ethiopia. The meteorological data was gathered from the National Meteorology Agency of Ethiopia including detailed local temperature and rainfall data from four weather stations in the study area.

The collected data were analyzed using the Statistical Package for Social Sciences (SPSS Version 26). Descriptive statistics were used to analyze the quantitative data, while qualitative data were coded and thematically analyzed. Coefficient variations (CV) were used to determine the level of rainfall variability in the study districts. When the CV was less than $20 \%$ it was considered as 'less variable'; 'moderately' variable when it was between 20 and 30\%; 'highly' variable when it was greater than $30 \%$; 'severely' variable when it was greater than $40 \%$, and a 
CV greater than 70\% indicated an 'extremely' high rainfall variability (Mazor et al., 2009). The data also examined Rainfall Anomaly $(X)$ which is deviations of annual rainfall from long-run averages. This was used to evaluate the variability pattern and drought level in the study district (Ayal \& Leal Filho, 2017).

\section{Findings}

This section presents the demographic characteristics of respondents-, the long-term impacts of climate change on farmers' livelihoods as observed by farmers, climate variability in the study districts, and climatic changes experienced by farm households.

\section{Demographic Characteristics}

Of the household heads surveyed for this study, $79.8 \%$ were male and $20.2 \%$ were female. Female household headship for the study area was slightly lower than the national average which was 22.1\% for rural areas (Central Statistical Agency [CSA], 2016). Nearly 39\% of survey respondents had not attended formal school and the education level of respondents was higher than the national average, in which $69.8 \%$ of the population had no education or had not attended primary school (CSA, 2016). Average age of respondents were 44.2 years with a minimum and maximum age of 35 and 76 years respectively. Mean household size of respondents were 6.3 persons/household compared to the national average of 4.9 persons/household in rural areas (CSA, 2016). Average landholding size for study respondents was 1.12ha per household, which is larger than that in the Wolaita Zone, where the average landholding size per household was 0.25ha (WZFEDD, 2017). The larger farm-holdings held by those surveyed can be explained by the fact that lowland farms tend to be much bigger than highland and midland farms in the zone. The survey found that around $48 \%$ of household heads possessed mobile phones, which is similar to the national average of $47.2 \%$ for rural households in Ethiopia (CSA, 2016) (see Table 1). 
Table1

Percentage Distribution of Farmers by District and Selected Demographic and Socio-economic Characteristics $(N=400)$

\begin{tabular}{|c|c|c|c|c|c|}
\hline \multirow[b]{2}{*}{ Household characteristics } & \multicolumn{5}{|c|}{$\%$ of Respondents } \\
\hline & $\begin{array}{l}\text { Total } \\
(\mathrm{N}=400)\end{array}$ & $\begin{array}{l}\text { Duguna } \\
\text { Fango } \\
(n=139)\end{array}$ & $\begin{array}{l}\text { Damot } \\
\text { Woyide } \\
(n=116)\end{array}$ & $\begin{array}{l}\text { Abala } \\
\text { Abaya } \\
(n=106)\end{array}$ & $\begin{array}{l}\text { Kindo } \\
\text { Koyisha } \\
(n=39)\end{array}$ \\
\hline Male household head & 79.8 & 78.4 & 76.7 & 84.9 & 79.5 \\
\hline Female household head & 20.3 & 21.6 & 23.3 & 15.1 & 20.5 \\
\hline Mean age of household heads (years) & 44.2 & 45.7 & 43.0 & 43.5 & 44.7 \\
\hline Mean household size & 6.3 & 6.2 & 6.5 & 6.3 & 6.0 \\
\hline \multicolumn{6}{|l|}{ Educational Status of household head } \\
\hline Did not attend primary school & 39 & 46.8 & 37.9 & 27.4 & 46.1 \\
\hline Attended primary school and above & 61 & 53.3 & 62 & 72.7 & 53.9 \\
\hline \multicolumn{6}{|l|}{ Household head farming experience } \\
\hline $20-30$ years & 85.5 & 84.9 & 86.2 & 86.8 & 82.1 \\
\hline $31+$ years & 14.5 & 15.1 & 13.8 & 13.2 & 17.9 \\
\hline $\begin{array}{l}\text { Average land size of household } \\
\text { (hectares) }\end{array}$ & 1.1 & 1.0 & 0.8 & 1.5 & 1.5 \\
\hline $\begin{array}{l}\text { Household heads that had a mobile } \\
\text { phone }\end{array}$ & 47.8 & 37.4 & 37.9 & 67.0 & 61.5 \\
\hline
\end{tabular}

Farmers' experience of farming was predicted to be a significant factor in determining their perceptions and awareness of their surroundings (Araro et al., 2020). The survey results presented in Table 1 show that all farmers had more than 20 years farming experience.

\section{Farmer Perceptions of long-term Climate Change}

Respondents have observed temperature and rainfall changes over the past 20 years (Table 2). Results show that almost all farmers (99.5\%) observed an increase in the frequency of extreme droughts over this time period, while the vast majority $(97.5 \%)$ of farmers observed that temperatures had increased. More than $77 \%$ of surveyed farmers observed that the frequency of rainfall variability had increased, and three quarters $(75.3 \%)$ of farmers had observed that the overall amount of rainfall had decreased with $17.3 \%$ suggesting it was 'more erratic'. 


\section{Table 2}

Percentage Distribution of Farmers by their Opinions on Climate Variability/Change over the Previous 20 Years (2000-2019) $(N=400)$

\begin{tabular}{llll}
\hline & \multicolumn{2}{c}{ \% of respondents } \\
Climate variability & Increase & Decrease & Moderate/constant \\
\hline Frequency of extreme droughts & 99.5 & 0.5 & - \\
Frequency of rainfall variability & 77.3 & 22.8 & - \\
Daily temperature change & 97.5 & 2.5 & - \\
Amount of the rainfall in each year & 7.5 & 75.3 & 17.3 ('more erratic') \\
\hline
\end{tabular}

Over $85 \%$ of respondents felt that the intensity of extreme drought over the previous 20 years had been 'severe' (stayed for a long period), and 7\% believed it had been 'extremely severe' (i.e., stayed for a very long period).

Furthermore, farmers in the FGDs were asked what climate changes occurred in their area in the last 20 years and what is causing it. One FGD participant, a man from Kindo Koyisha Village, stated that one of the reasons may be that:

God might have been punishing us for doing awful work, simultaneously noting that the land is drier with very small production harvested each year and, I plant different types of trees to shade, however, they didn't withstand the hot weather. Several other participants didn't agree, describing the reason being due to the illegal cutting of trees.

\section{Temperature Change and Rainfall Variability}

This section presents temperature and rainfall variability in the study districts based on 20 years of climate data between the period2000 to 2019.

The National Meteorology Agency temperature data (Figure 2) shows that average maximum high daytime temperatures (excess of $30^{\circ} \mathrm{C}$ ) were observed in seven out of the recorded twenty years, while the minimum high daytime temperature was observed in five of the twenty years (temperature over $17^{\circ} \mathrm{C}$ ). This suggests that there has been high temperature variability over the past 20 years in the study district. 


\section{Figure 2}

Average Annual Minimum and Maximum Temperatures in the Study Area (2000-2019)

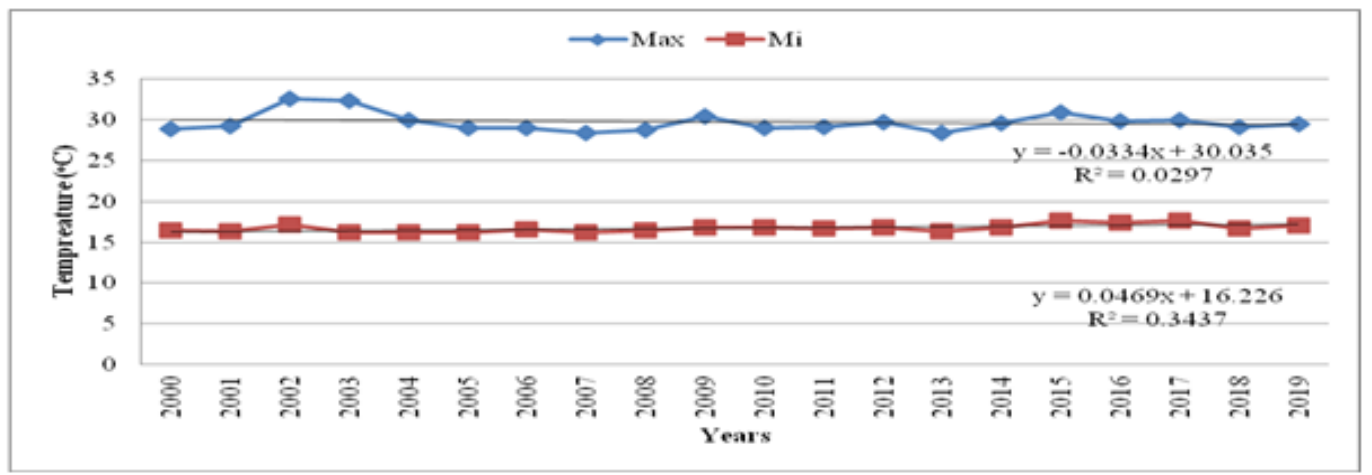

Source: National Meteorology Agency of Ethiopia (Hawassa branch)

Note. The data in Figure 2 was extracted by Agency staff specifically for this study from the local branch of the National Meteorology Agency of Ethiopia.

Rainfall data for the study area is presented in Figure 3 and suggests that the annual rainfall variability among four stations of the study district was highest in Bele. The data for the study area shows that the minimum average annual rainfall was $703.1 \mathrm{~mm}$ while the maximum average was $1362.35 \mathrm{~mm}$ (Figure 3) indicating a high rainfall variability in the study district.

\section{Figure 3}

Average Annual Rainfall for Lowlands of Wolaita Zone

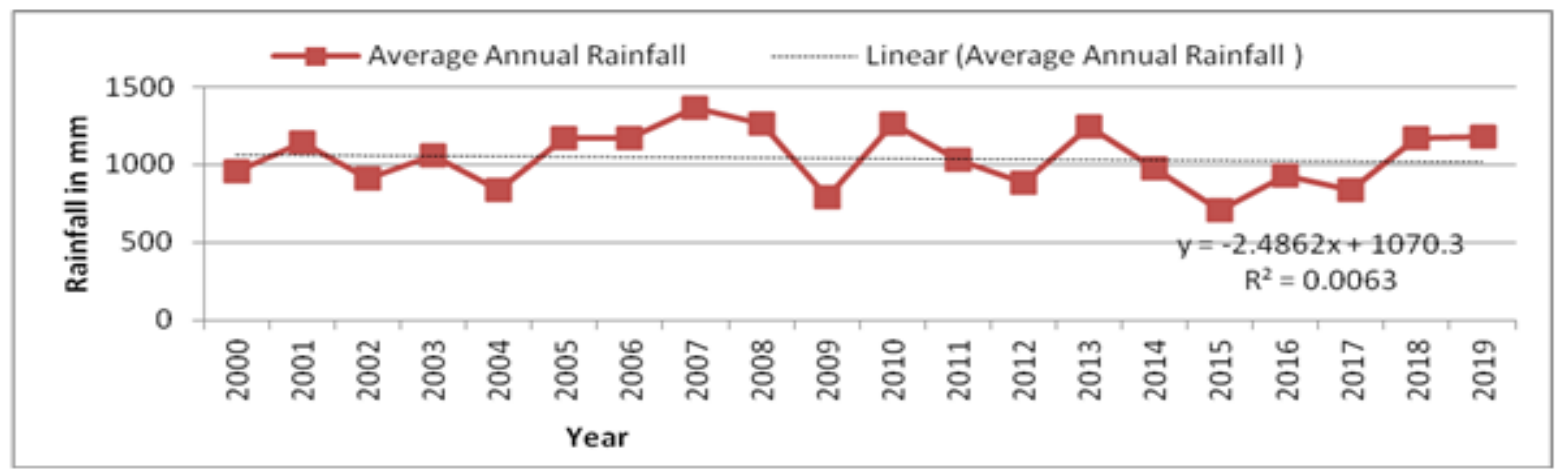

Source: National Meteorology Agency of Ethiopia (Hawassa branch)

Note. The data in Figure 3 was extracted by Agency staff specifically for this study from the local branch of the National Meteorology Agency of Ethiopia.

As indicated in Table 3, seasonal rainfall variability was observed in the study districts. Though high rainfall variability was experiential in all seasons, extremely high rainfall variability was observed in the Bega season with a CV greater than $70 \%$. The variability was severe in the Meher and Belg seasons with the CV greater than $40 \%$. 


\section{Table 3}

Seasonal Average Rainfall ( $\mathrm{mm}$ ), for Four Meteorology Stations in the Study Area (2000-2019)

\begin{tabular}{|c|c|c|c|c|c|c|c|c|c|c|c|c|}
\hline \multirow{3}{*}{ Stations } & \multicolumn{12}{|c|}{ Seasons } \\
\hline & \multicolumn{3}{|c|}{$\begin{array}{l}\text { Bega (Winter) } \\
\text { (Dec., Jan., Feb.) }\end{array}$} & \multicolumn{3}{|c|}{$\begin{array}{l}\text { Tseday (Spring) } \\
\text { (Mar., Apr., May.) }\end{array}$} & \multicolumn{3}{|c|}{$\begin{array}{c}\text { Meher (Summer) } \\
\text { (Jun., July, Aug.) }\end{array}$} & \multicolumn{3}{|c|}{$\begin{array}{l}\text { Belg (Autumn) } \\
\text { (Sep., Oct, Nov.) }\end{array}$} \\
\hline & $S D$ & $M$ & $C V$ & $S D$ & $M$ & $C V$ & $S D$ & $M$ & $C V$ & $S D$ & $M$ & $C V$ \\
\hline Bedessa & 56.5 & 82.8 & 68.2 & 107.2 & 389.9 & 27.5 & 119.4 & 392.8 & 30.4 & 90.3 & 268.4 & 33.7 \\
\hline Bele & 68.6 & 73.2 & 93.8 & 122.5 & 340.6 & 35.9 & 256.2 & 479.8 & 53.4 & 87.5 & 263.1 & 33.3 \\
\hline Billate & 49.5 & 67.1 & 73.7 & 103.6 & 286.9 & 36.1 & 75.8 & 245.3 & 30.9 & 70.1 & 217.2 & 32.3 \\
\hline Humbo & 91.5 & 79.1 & 115.7 & 126.7 & 353.4 & 35.9 & 153.8 & 445.9 & 34.5 & 146.6 & 267.2 & 54.9 \\
\hline
\end{tabular}

Source: National Meteorology Agency of Ethiopia (Hawassa branch)

Note. The data in Table 3 was extracted by Agency staff specifically for this study from the local branch of the National Meteorology Agency of Ethiopia.

The rainfall anomaly (Figure 4) shows the presence of annual rainfall variability over the previous 20 years in the study area. The negative and positive values in Figure 4 indicate the availability of dry and wet years in the study district. Based on rainfall anomaly value $(X)$, Agnew and Chappell (1999) classified drought into four categories. When the $X$ value is less than -1.65 , it is classified as 'extreme' drought. 'severe' drought occurs when -1.28 $>X>-1.65$, 'moderate' drought is found when $-0.84>X>-1.28$, and when the $X$ value is greater than -0.84 , it indicates 'no drought'. The rainfall anomaly values for the study area found the range between the highest values of 1.69 in the year 2007 to the lowest value of -1.82 in the year 2015 . The results show that 2015 was found to be in extreme drought while 2009 was in severe drought. The years 2004, 2012, and 2017 are classified as being in moderate drought whilst 2007, 2008, 2010, 2013, and 2019 were found to be rainy (wet) years.

Figure 4

Rainfall Anomaly of the Study Area

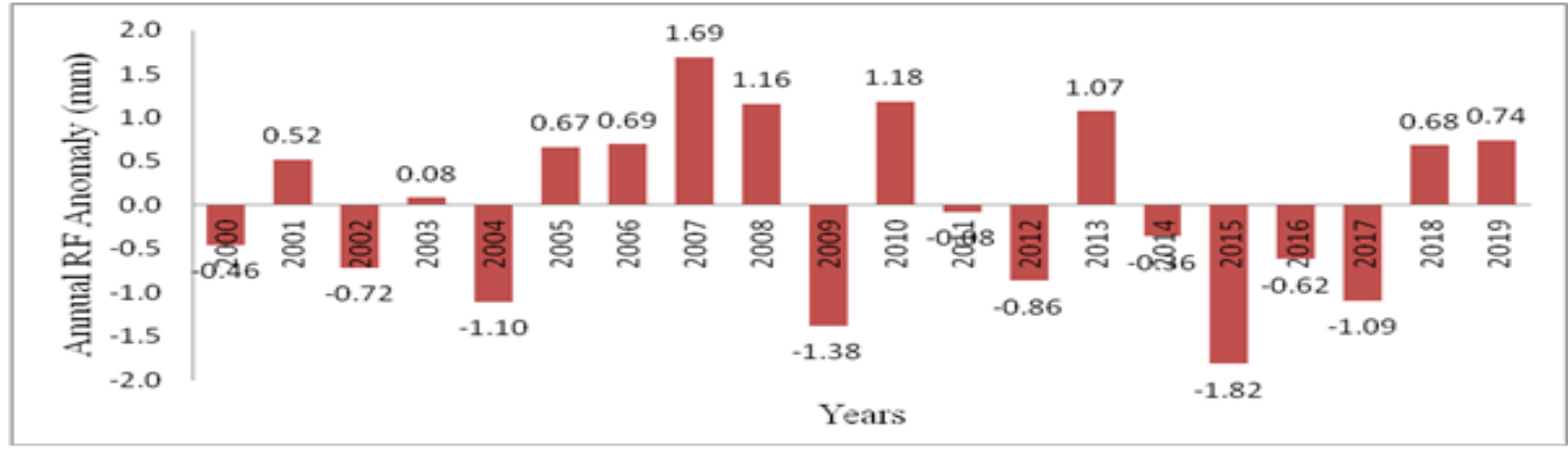

Source: National Meteorology Agency of Ethiopia (Hawassa branch) Note. The data in Figure 4 was extracted by Agency staff specifically for this study from the local branch of the National Meteorology Agency of Ethiopia. 


\section{Climate Changes Experienced by Farm Households}

This section relates to the third objective of the study. It presents the farmer-reported changes associated with crop production, crop losses, and climate-related diseases.

\section{Changes in Crop Production}

The impact of climate variability and changes in crop production in the past 20 years (20002019 ) is presented in Table 4 . The finding revealed that over $93 \%$ of farmers reported a decline in crop yields and overall incomes from agriculture. A large proportion of respondents (97\%) have observed increased partial or total crop failure, while more than $95 \%$ of respondents have reported an increasingly shortened growing season. Both rainfall and temperature variability have affected the overall conditions of farmers' livelihood through its impact on crop yields, crop failures, shifting cropping calendars, increasingly delayed planting dates, changes in crop varieties, soil erosion, and pest and disease prevalence. The impact of climate change had contributed to a decline in land use and land cover change.

\section{Table 4}

The Distribution of Farmers by the Response to the Impact of Climate Variability and Changes in Crop Production in the Previous 20 Years (2000-2019) $(N=400)$

\begin{tabular}{llll}
\hline Change on crop production & \multicolumn{3}{c}{ \% of respondents } \\
& Increased & Declined & Same \\
\hline Crop yield & 4.3 & 93.3 & 2.5 \\
Partial or total crop failure & 97.0 & 1.0 & 2.0 \\
Shortened length of the growing season & 95.3 & 3.5 & 1.3 \\
Shift in cropping calendar (delayed planting date) & 98.5 & 1.3 & 0.3 \\
Change in crop varieties & 98.3 & 1.5 & 0.3 \\
Pest and disease prevalence & 99.8 & 0.3 & - \\
Soil erosion & 72.5 & 27.3 & 0.3 \\
Land use/land cover change & 8.8 & 90.0 & 1.3 \\
Income from agriculture & 0.5 & 99.0 & 0.5 \\
\hline
\end{tabular}

Regarding this, focus group members were asked about how climate changes impact their crop production. An FGD participant, a man from Abala Sipa Village, stated that:

During the main rainy season, the rain comes late and then as nonstop heavy rains continuously rain for several weeks; or else, the rain comes sooner and then stops for several weeks.

This situation forced him to change the crop planting date. Several other participants agreed, describing as "a result, we couldn't able to feed our family members throughout the years."

\section{Crop Loss}

All surveyed farmers reported that over the previous 20 years, flood affects their farms on five or more occasions, and some farmers (6.8\%) reported it was more than five times. In the study area, farmers plant different types of crops namely, maize, haricot bean, sorghum, barley, teff, 
onion, pepper, yam, and coffee on their farms. Pigeon pea and haricot bean are typically used in intercropping with maize however, the dominant crop in the study area is maize. Some $73 \%$ of farmers reported that they had experienced crop losses in the previous production season (2019) with the rest $(27 \%)$ reporting that they had not been affected. The study findings indicated that more than two out of every three farmers (66\%) had lost about 0.32 ha of maize crops in the reported production season (see Table 5).

\section{Table 5}

The Distribution of Farmers by Losses of Crops Experienced in the Last Production Season ( $N=$ 400)

\begin{tabular}{llll}
\hline & & $\%$ & $\begin{array}{l}\text { Average crop loss in } \\
\text { hectares/ } \\
\text { household }\end{array}$ \\
\hline Types of crop loss & Frequency & $\% 6.0$ & 0.32 \\
Haize & 264 & 2.8 & 0.25 \\
Barley & 11 & 0.3 & 0.30 \\
Teff & 1 & 1.8 & 0.26 \\
Paper & 7 & 0.8 & 0.26 \\
Onion & 3 & 0.8 & 0.26 \\
Yam & 3 & 0.8 & 0.26 \\
No & 3 & 27.0 & - \\
\hline Total & 108 & 100 & \\
\hline
\end{tabular}

Regarding this, focus group members were asked questions related to climate changes' impact on their crop production. A participant in the focus group, a woman from Tora Sadebo Village, stated that "Flood comes in each heavy rainy season and it totally or partially damaged the planted crops, eroded cultivated and communal land." All other participants agreed, describing "heavy rain eroded our land and damages the community residences." They explain that "increment in temperature causes the 'Maize Virus' which mainly affects the maize crops."

\section{Climate-related Diseases}

Malaria is a vector-borne disease that is linked to climate change (Simane, 2016; Wu et al., 2016). The study findings show that $82 \%$ of the respondents had experienced malaria, and just over half (51.5\%) reported that the health status of animals was 'bad'. Farmers were interviewed on how climate changes impact human and animal health. A man from Abala Maraka village took part in the focus group and discussed his experiences and associated feelings as:

The temperature increases, the prevalence of the malaria epidemic and Tsetse flies increases within the community. Our animals are mostly affected by Tsetse flies (Tryponsomises). It is sad to share you this ... but our livestock were died in respective years due to climate variability. 
Subsequently he noted that "the remaining animal is not healthy because of the shortage of feed." Other participants share his views by noting "more lands were out from cropping because of the unavailability of oxen for plowing."

\section{Conclusions, Discussion, and Recommendations}

The farmers in the study area reported an increase in long-term temperature as well as declining rainfall which are in line with local weather records. Farmers' observations of increasing temperatures are congruent with Bongaarts (2019) and the Ethiopian Panel of Climate Change's (Ethiopian Panel on Climate Change [EPCC], 2015) findings that the country's average temperature has risen over the past five decades (at a rate of 0.2 degrees $C$ per decade). Excerpts from the focus groups also confirmed an increase in daytime temperatures and a decline in annual rainfall in the study area.

Crop yields and productivity in the study area are influenced by rainfall patterns in both the Belg and Meher seasons. The Meher season production is tremendously important as it accounts for $92 \%$ of the total area cultivated and more than $96 \%$ of total crop production (Tafesse et al., 2011). Results revealed that in the main production season, the rainfall pattern was extremely unpredictable and erratic in the study area. The computed coefficient variation for annual and seasonal rainfall variability in the study district suggests a lot of inter-annual and intra-annual rainfall variability. According to findings from the focus groups, the study district does not receive adequate rainfall during the main cropping period (Meher). These variations highly impact on agricultural production as well as farmers' lives in general. These findings are consistent with those of Bedeke et al. (2018), Habtemariam et al. (2016), and Mihiretu et al. (2020). By way of response, drought-resistant crops and water harvesting schemes could be developed to reduce the affects of climate change.

The temperature distribution in the study district is characterized by a general increase and a few inter-annual changes. Both yearly maximum and minimum temperatures recorded at the study area meteorology stations have increased. Rainfall anomaly results revealed that there were five drought years and five wet (rainy) years between 2000 and 2019. The results indicated that within three or four year intervals, major climatic variability was observed in the study district. The climate data findings were also comparable with farmers' observations and indicated that their crops had been flooded at least five times in the previous 20 years. This finding also aligns with the study conducted by Araro, et al. (2020) in the Konso District of Southern Ethiopia and with the World Bank's Assessment Study (World Bank, 2010). The report from the World Bank showed that droughts and floods were common occurrences in the country, happening every three to five years.

The farmers in the study area reported that crop losses were due to rainfall variability, high temperatures, floods, and crop diseases (mainly 'Maize Virus'). The findings suggest that climate variables and the livelihood of farmers are connected. Climate-related diseases such as malaria and tsetse flies highly impact both human and animal well-being (Parham et al. 2015; 
Pagabeleguem et al., 2016). As farmers noted in the FGD, the increment of temperature was conducive to the prevalence of the malaria epidemic in the study area. Diseases (Tsetse flies) due to the variability of weather conditions and shortage of feed were seen as major causes of poor animal health. Matewos (2019) reported malaria, cholera, and animal diseases were the most common epidemics attributed to climate change and variability.

The scientific explanations of climate changes have mostly concentrated on anthropogenic greenhouse gas emissions, caused by human activities (NRC, 2020). According to FGD, some farmers in the study area consider adverse weather conditions connected with spiritual causes as punishments from God, while the others recognized the contribution of human activities such as deforestation, overgrazing, and demographic pressures. Filling the knowledge gap through training of all stakeholders is crucial to their understanding of the causes of climate change variability at the local level.

\section{Acknowledgements}

This study was funded by European Union's Horizon 2020 research and innovation programme under the Marie Sktodowska-Curie grant agreement No 778196. However, the contents of the paper reflect only the author's view and that the Agency is not responsible for any use that may be made of the information it contains.

\section{References}

Abidoye, B. O., \& Odusola, A. F. (2015). Climate change and economic growth in Africa: An econometric analysis. Journal of African Economies, 24(2), 277-301. https://doi.org/10.1093/jae/eju033

Agnew, C. T., \& Chappell, A. (1999). Drought in the Sahel. Geojournal, 48(4), 299-311. https://doi.org/10.1023/A:1007059403077

Araro, K., Legesse, S. A., \& Meshesha, D. T. (2020). Climate change and variability impacts on rural livelihoods and adaptation strategies in Southern Ethiopia. Earth Systems and Environment, 4(1), 15-26. https://doi.org/10.1007/s41748-019-00134-9

Auci, S., Castellucci, L., \& Coromaldi, M. (2018). The impact of climate change on the distribution of rural income in Ethiopia. International Journal of Environmental Studies, 75(6), 913-931. https://www.tandfonline.com/doi/full/10.1080/00207233.2018.1475914

Ayal, D. Y., \& Leal Filho, W. (2017). Farmers' perceptions of climate variability and its adverse impacts on crop and livestock production in Ethiopia. Journal of Arid Environments, 140, 20-28. https://doi.org/10.1016/j.jaridenv.2017.01.007 
Bedeke, S. B., Vanhove, W., Wordofa, M. G., Natarajan, K., \& Van Damme, P. (2018). Perception of and response to climate change by maize-dependent smallholders. Climate Research, 75(3), 261-275. https://doi.org/10.3354/cr01524

Bekele, M., Bezabih, M., Elias, H., Fisker, P., Gebrehiwot, T., Kuma, T., Mekasha, T., Mekonnen, A., Tarp, F., \& Teklewold, H. (2020). Building resilience to climate change in Ethiopia what do we know so far? Development Economics Research Group. https://www.econ.ku.dk/derg/wps/01-2020.pdf

Belay, A., Demissie, T., Recha, J. W., Oludhe, C., Osano, P. M., Olaka, L. A., Solomon, D., \& Berhane, Z. (2021). Analysis of climate variability and trends in southern Ethiopia. Climate (Basel), 9(6), 96. https://doi.org/10.3390/cli9060096

Bongaarts, J. (2019). Intergovernmental panel on climate change special report on global warming of $1.5^{\circ} \mathrm{C}$ Switzerland: IPCC, 2018. Wiley. https://doi.org/10.1111/padr.12234

Central Statistical Agency. (2016). Ethiopia demographic and health survey. https://dhsprogram.com/pubs/pdf/FR328/FR328.pdf

Cochran, W. G. (1977). Sampling techniques. Wiley.

Crippa, M., Solazzo, E., Guizzardi, D., Monforti-Ferrario, F., Tubiello, F. N., \& Leip, A. (2021). Food systems are responsible for a third of global anthropogenic GHG emissions. Nature Food, 2(3), 198-209. https://doi.org/10.1038/s43016-021-00225-9

Department for International Development, Londen. (1999). Sustainable livelihoods guidance sheets. Emergency Nutrition Network. https://www.ennonline.net/attachments/872/section2.pdf

Ethiopian Panel on Climate Change. (2015). First assessment report, working group II agriculture and food security. Ethiopian Academy of Sciences.

Georgis, K. (2015). Planning national adaptation responses to climate change. A Repository of Agricultural Research Outputs. https://hdl.handle.net/10568/65079

Habtemariam, L. T., Gandorfer, M., Kassa, G. A., \& Heissenhuber, A. (2016). Factors influencing smallholder farmers' climate change perceptions: A study from farmers in Ethiopia. Environmental Management ,58(2), 343358. https://doi.org/10.1007/s00267-016-0708-0

Intergovernmental Panel on Climate Change. (2018). Global warming of $1.5^{\circ} \mathrm{C}$. https://www.ipcc.ch/sr15/download/ 
Irish Aid. (2017). Ethiopia climate action report for 2016: Resilience and economic inclusion team.

https://www.irishaid.ie/media/irishaid/allwebsitemedia/30whatwedo/climatechange/E thiopia-Country-Climate-Action-Reports-2016.pdf

Kaddo, Jameel R. (2016). Climate change: Causes, effects, and solutions [A honors project]. Parkland College. http://spark.parkland.edu/ah/164

Kolawole, O. D., Motsholapheko, M. R., Ngwenya, B. N., Thakadu, O., Mmopelwa, G., \& Kgathi, D. L. (2016). Climate variability and rural livelihoods: How households perceive and adapt to climatic shocks in the Okavango Delta, Botswana. Weather, Climate, and Society, 8(2), 131-145. https://doi.org/10.1175/WCAS-D-15-0019.1

Matewos, T. (2019). Climate change-induced impacts on smallholder farmers in selected districts of Sidama, southern Ethiopia. Climate, 7(5),70. https://doi.org/10.3390/cli7050070

Mazor, R. D., Purcell, A. H., \& Resh, V. H. (2009). Long-term variability in bioassessments: A twenty-year study from two northern California streams. Environmental Management, 43(6), 1269-1286. https://link.springer.com/content/pdf/10.1007/s00267-009-9294-8.pdf

Mihiretu, A., Okoyo, E. N., \& Lemma, T. (2020). Small holder farmers' perception and response mechanisms to climate change: Lesson from Tekeze lowland goat and sorghum livelihood zone, Ethiopia. Cogent Food \& Agriculture, 6(1). https://doi.org/10.1080/23311932.2020.1763647

Moroda, G. T., Tolossa, D., \& Semie, N. (2018). Perception and adaptation strategies of rural people against the adverse effects of climate variability: A case study of Boset District, East Shewa, Ethiopia. Environmental Development, 27, 2- 13. https://doi.org/10.1016/j.envdev.2018.07.005

National Meteorology Agency of Ethiopia. (2020). Local branch of the National Meteorology Agency Awassa, Ethiopia.

National Research Council. (2020). Climate Change: Evidence and Causes: Update 2020. The National Academies Press. http://nap.edu/25733

Pagabeleguem, S., Ravel, S., Dicko, A. H., Vreysen, M. J. B., Parker, A., Takac, P., Huber, K., Sidibé, I., Gimonneau, G., \& Bouyer, J. (2016). Influence of temperature and relative humidity on survival and fecundity of three tsetse strains. Parasites \& Vectors, 9(1), Article 520. https://doi.org/10.1186/s13071-016-1805-x 
Parham, P. E., Waldock, J., Christophides, G. K., \& Michael, E. (2015). Climate change and vector-borne diseases of humans. Philosophical Transactions of the Royal Society $B$ : Biological Sciences, 370(1665), Article 20140377. https://doi.org/10.1098/rstb.2014.0377

Simane, B., Beyene, H., Deressa, W., Kumie, A., Berhane, K., \& Samet, J. (2016). Review of climate change and health in Ethiopia: Status and gap analysis. Ethiopian Journal of Health Development, 30(1), 28-41. https://www.ajol.info/index.php/ejhd/article/view/147317

Taffesse, A. S., Dorosh, P., \& Gemessa, S. A. (2011). Crop production in Ethiopia: Regional patterns and trends [Working document]. International Food Policy Research Institute https://reliefweb.int/sites/reliefweb.int/files/resources/essprn11.pdf

Tessema, I., \& Simane, B. (2020). Smallholder farmers' perception and adaptation to climate variability and change in Fincha sub-basin of the Upper Blue Nile River Basin of Ethiopia. GeoJournal, 86, 1767-1783. https://doi.org/10.1007/s10708-020-10159-7

Trenberth, K. E. (2018). Climate change caused by human activities is happening and it already has major consequences. Journal of Energy \& Natural Resources Law, 36(4), 463-481. https://doi.org/10.1080/02646811.2018.1450895

Wolaita Zone Finance and Economic Development Department. (2017). Annual statistical abstract of Wolaita Zone. Finance and Economic Development Department Wolaita Sodo, Ethiopia.

World Bank Group. (2010). Economics of adaptation to climate change: Ethiopia. https://openknowledge.worldbank.org/bitstream/handle/10986/12504/686500ESWOP1 130UBLICOOEACCOEthiopia.pdf?sequence $=1$ \&isAllowed $=y$

Wu, X., Lu, Y., Zhou, S., Chen, L., \& Xu, B. (2016). Impact of climate change on human infectious diseases: Empirical evidence and human adaptation. Environment International, 86, 1423. https://doi.org/10.1016/j.envint.2015.09.007

(C) 2022 by authors. This article is an open access article distributed under the terms and conditions of the Creative Commons Attribution license (http://creativecommons.org/licenses/by/4.0/). 